\title{
Deep Democracy, Horizontal Exchange and the Praxis of Poop
}

The politics of shit-as Gandhi showed in his own efforts to liberate the lowest castes, whom he called Harijans, from the task of hauling uppercaste ordure-presents a node at which concerns of the human body, dignity and technology meet, a nexus the poor are now redefining with the help of movements like the [SDI] Alliance. In India, where distance from one's own faeces can be seen as the virtual marker of class distinction, the poor, for too long having lived literally in their own faeces, are finding ways to place some distance between their waste and themselves. The toilet exhibitions are a transgressive display of this faecal politics, itself a critical material feature of deep democracy.

Arjun Appadurai, $2001^{1}$

Entries from a research-activist's diary, observing some examples of thinking globally and shitting locally.

—Byculla, INDIA, November 2003 
Day 1

After a powerfully curried breakfast, the jet-lagged South African group (Ndumiso and five SAHPF $^{2}$ Mamas from Kwa-Zulu Natal) and I, who are here to study toilet construction (in other words, a 'shit delegation') trundle dazed along the rampant streets of Byculla. The adrenalin soon wakes us up, as we precariously pick our way through sleeping, washing and working people, dodging a poop here, avoiding a truck there. We're headed to where Jockin is holding court. Jockin is the head of the National Slum Dwellers Federaton (NSDF) and elected 'emperor' of Shack/Slum Dwellers International (SDI).

In an open-fronted meeting hall in the thick of the Byculla slum Jockin is alone and on the phone. In adjacent rooms, members of the NSDF Ministry of Finance are busy. The quiet murmur of voices contrasts with the raucous street-sounds now obscured by the building, courtyard and wall. A sense of calm industriousness prevails. Women are entering the premises to hand over cash and savings books. Seated on the floor all about are folk reconciling ledgers, counting rupees, signing receipts, phoning and tapping away at computers. It is a bit like a working bank. But without the anonymity. Here everyone knows each other. There is a certain domesticity about it all. Little trays of sickly sweet, milk-boiled tea circulate. So does gossip and advice. Community is knitted with simple things.

Jockin welcomes us, and a second breakfast of fruit and tea arrives. He wants to hear from the group what their expectations are. He obliges us to reflect on why we are here.

Jockin: 'What do you want?'

South African Toilet Team (SATT): 'We want to learn from India about toilets.'

Jockin: 'Individual or communal?'

SATT: 'Communal toilets. And also to get lessons in savings-we want to see daily savings in action. To witness the Indian process, to see it first-hand, because you Indians were the initiators of savings. We need to learn more. For example in our system, we don't have withdrawals-we don't know how to do withdrawals. We want to watch how you do it and discover how it works.'

Jockin: 'What did you think when you left your country? What did you dream when you left?' 
SATT: 'We want to see toilets! Durban City has now an alliance with the South African Homeless Peoples Federation to build toilets. There is now a joint Federation/Health/Metro/ Settlement steering committee. We are here to learn from the Indian experience. To directly study the process. From the beginning to the end of the project. We want a blueprint to take back!'

Listening closely, Jockin seeks to marry their agenda with what Mumbai has to offer. Slum dweller banking—savings, withdrawals, loans—and, of course, slum dweller toilets. Money and shit. Freud would have raised an eyebrow.

Jockin begins: 'Our topic is shit, and the management thereof ...'

It appears that the federation in Mumbai has built over 240 toilet blocks in two years. These are of every possible type: water-borne sewers, pit latrines, buckets, septic tanks, bio-recyclable and truck-pumped. There is no fixed method (a sad surprise to our team, who would prefer the rote approach, sans contingency). Instead, the local committees create the appropriate waste technology for the specific geography and location. Furthermore, in every case the construction details are uniquely tailored. These projects can be team-built or use individual contractors; they can be externally aided or exclusively federation-built ...

'So Mamas?' Now knowing the South African requirements, Jockin decides on us viewing four toilet blocks today. These would be both sewer and pit-based blocks, with different management arrangements. They will teach us the Five MITs (most important things) about toilet building:

1. Location

2. Building community

3. Design

4. Construction model

5. Toilet maintenance.

Our guide to it all is Shamila, elegant, doe-eyed and cheerful. We set forth through the teeming streets in a deliciously chilled mini-bus. I irritate everyone by winding down the windows to take pics. The loos are in different areas. In each place poverty prevails, yet with a different flavour. All are in deeply congested locations. Before the building of these toilet blocks, one toilet would service nearly a thousand people. The joke at the time was that if you waited in line to use the toilets you would have to wait for eighteen days! 
Whatever.

What we see are clean and hospitable ablution facilities, islands of hygiene in a sea of filth and urban squalor. Well-maintained by either a resident manager or a committee, they provide toilet, bathing, laundry and communal meeting facilities. Some

\section{What is SDI?}

Shack/Slum Dwellers International (SDI) is an international network of the 'poorest of the poor', the 'weakest of the weak', who share ideas and experiences, and support one another in gaining access to the resources they lack (such as adequate land, infrastructure and housing), while also dealing with a plethora of issues that typify the milieu of poverty (such as HIV/AIDS, pollution, violence and exploitation). SDI brings together poor women and men from slum settlements through national and international exchange visits, exhibitions and meetings to enable the direct and rapid transfer of knowledge, experiences and skills among organisations of the very poor.

SDI is neither a supranational non-government organisation (NGO) nor a development agency. It is rather a transnational social movement made up of community-based organisations committed to a shared process of grassroots organisation (federations), problem-solving and solution-sharing. An international SDI secretariat helps to coordinate these activities, but the primary focus of the network's activities is emphatically local.

The strength of SDI lies in the combination of its local and global dimensions. Strong local organisations of the poor are built on the foundation of community savings schemes. These communities gather information about their own settlements and use this information to explore collective community-led solutions to the needs they identify as most salient for their communities. These local federations, supported by a professional NGO, become part of a global network of organisations facing similar challenges engaged in an ongoing exchange process. Communities learn to see their own situation in a new light, to share their own knowledge and to learn from the experiences of others. The lessons learnt are then adapted to the local context. Success is exemplary and can be used as leverage to access resources, or to make demands. SDI is a social movement based around the creation of choice in a milieu vacant of choice. It does this through the exchange of people and their knowledge. Grassroots wisdom is linked worldwide to empower the 'poorest of the poor', while global collectivity is used to strengthen the 'weakest of the weak'. 
even have TVs in the communal areas. All have large, bright and colourful loos for children, designed by children and reflecting their needs. Built on a smaller scale to accommodate their size, they are well lit and ventilated, and, most significantly, they are collectively open to prohibit molestation.

The toilet blocks are all run a bit like northern health clubs: there is a caucus of paid-up members, each with a photo-id card, who contribute a small monthly sum to belong, over and above an initial joining fee. The initial fee, sometimes paid for through a micro-loan from their savings scheme, actually amounts to a considerable reduction on what the poor would have paid for water before the facility. (Due to the lack of infrastructure and the unavoidable private sale of water, the poor, it is estimated, often pay up to ten times the amount others pay for potable water.) Like the Romans, crapping together builds openness, collectivity and community (in neo-liberal speak, 'social capital'). Our team is impressed and agrees to meet again the next day with a toilet committee, to walk through the planning and construction process.

Day 2

Ian and Malc of Homeless International (HI) pick me up. We take a cab thru to the SPARC $^{3}$ offices in old Mumbai. These are located in an abandoned school, the bottom floors of which are being used again as a school and creche for the children of prostitutes. The carers and teachers, as I understand it, are from these ranks too.

The SPARC offices are a beehive of activity. I meet Sheela Patel, who presents me warmly to her staff, and I ease into the place. I am introduced to Ruth McLeod of HI, and have a lesson in CD graphics with the AV boffin Indu. In between show and tell, the hours are filled with meeting fellow NGO vultures: various slum-supporters, gutter groupies and poverty parasites. I have a crowd of new acquaintances by day's end. To celebrate our happy encounter we cab over to one of the office lasses' homes. Dense clouds of incense smoke, opulence and icy drinks await us. It is a refined, ultrabourgeois evening in the home of a director of City Bank. Talk of travel, Oxford and theatre abounds. It is a far cry from the pavement dwellers outside. I marvel at the capacity for do-gooders to revert to class once out of the office. The beer is refreshing and ample. I lightly offend everyone with tales of violence, cannibalism and muti in Africa-and cheerfully taxi home through the tepid night. 
Day 3

Prince Charles, the big-eared, unhinged blue blood is the trick of the day, today. I am to be part of the video team. There are three of us-Indu, Malc and I-each, for security reasons, on a different level of the federation-built housing project, which the bonnie prince is officially opening. Rajiv Indira is a five apartment-block housing construction built to rehouse 209 families that live in Dharavi, reputedly Asia's largest slum. This project is particularly important to the federation for a number of reasons. It is the first time such a scheme is being led entirely by poor communities and hereby demonstrates how these communities can manage and direct slum upgrading. Moreover, by showing that such projects, which focus on the needs of the poor, ensure high quality construction and financial sustainability, it sets new standards in the city-and creates a demand for similar constructions. Finally, it tests the city's redevelopment policy to see how it works for poor communities. As a result, a wealth of experience is generated, magnifying the capacity of the poor and ensuring a regular stream of local, national and international visitors to the site, all coming to see and learn from the project.

Well, today the place is ablaze with colour. The hundreds of federation and Mahila Milan $^{4}$ women are bright as blossoms in their vivid saris. The African contingent is comfortably ensconced up front. I am up on a box balancing a VCR on a monopod. Big Ears lands with much 'Namaste's and bowing. Garlands of flowers and curtseys. He mutters a few homilies and platitudes.

The interesting thing is to see how rapidly Jockin takes control of the situation. Despite the security protocols, the diplomatic staff and associated lackeys, there is a subtle vacuum around the prince. This zone of inhibition is immediately occupied/squatted by Jockin. The prince is understandably confused by the riot of colour and haphazard slum geography. The slum dweller leads him. Big Ears foolishly questions the need for high-rise structures (remember he is chairman of the Vernacular Architects Society and dislikes anything over three stories-or the height of Buckingham Palace). Jockin takes advantage of a narrowing in the path and a gap in the corrugated iron and steers him straight into the thick of the slum. The pressing crowds immediately close around them. The bodyguards are stuck bewildered outside. The High Commissioner's stiff upper lip is taxed. The staffers and pompous twits in little white sailor suits begin to fret and quietly panic. The man with the blood bags in the 
refrigerated suitcase is paralysed. Decorum! Decorum! Don't let the natives see your fear ... The prince and Jockin spend quite some time in the shit-sodden, filth-strewn alleys, forcing their way through blockages of curious bystanders, and entering some of the hovels deep inside the murky realm. They eventually emerge with the prince looking stirred but not shaken. His demeanor has profoundly altered. He now leans toward Jockin intimately. He is all fired up. He is attentive and very interested. He listens. He is fascinated. To give credit to the bugger, he shows no sign of distaste or horror. His shoes are besmirched with human kaka, his suit rumpled from the throng, his hair ruffled and awry (the comb-over forlornly flapping). But he looks like a kid who has done well at school.

I realise the truth. Moreover, I stake my intellectual property rights upon this realisation. This is not the extension of citizenship. It is not the 'deep democracy' that Appadurai is describing. No, in the postmodern vacuum, in the legitimacy crisis faced by the state (and even more so by blue bloods), it is the poorest of the poor who, in their familiarity with the void, are leading the dance. In the anarchic limbo that is the postmodern, post- development reality, it is the federalists and mutualists from the realm of the excluded who know the ropes, and the representatives of the formal 'modern' world who seek their guidance. The beggar leads the blind king. Jockin operates the prince like a hand puppet. Soon the bonnie pee is promising heaps of pounds/euros. It is quite pathetic. In the 'I'll buy your friendship' fashion of Fauntleroy.

The prince goes up and about, and returns to boldly (and much to his own surprise) smash a coconut on the stairs of the building-a traditional sign of festivity (someone said that this originated in village funerals). The royal procession departs and the feeding of the masses commences. Giant urns are trundled up on high-wheeled carts, trestle tables buckle under tubs of rice. With machined discipline and speed, a gang of slum men dispenses the food, using a roving chain of hands to propel piled plates to all. Occasionally urchins sneak across the swinging arms and snatch the food, to run gleefully away with the loot. No one really minds, just some token bellows to give the game some authenticity. It is a moment of generosity. A prince has communed with the beggars and the whores. The unthinkable in terms of caste and history has happened. Songs break out, the South Africans rivalling their Indian hosts in voice. Sticky with saffron-stained faces and fingers, the chorus resounds joyfully. 
Day 4-

The following days are spent either in the SPARC offices or in the field with the group. One meeting with a toilet committee takes place over a number of hours in the actual toilet. Surrounded by huffing and puffing poopers, the group moved toward the only open space-that is, the children's section. With kids coming in droves to do their business in full view and nose, it was quite a shock to the sensibilities of our Mamas. It did seem, however, to accelerate learning and add a new dimension to 'horizontal exchange'.

My last day

I take a trip out to the suburbs (huge high-rise suburbs, that is) to have lunch with two friends. The taxi driver gets lost, so we stop outside a huge tenement block miles from where we are meant to be and I ask a man directions. Remarkably, he is one of the federation members, who attended the royal occasion too. He recognises me immediately and brandishes his HRH-VIP lapel badge. Forthwith, he decides to accompany us on our way and direct us in person. As he enters, both he and the taxi driver exclaim and warmly embrace, for they both come from the same rural area and know each other well. In a city of twelve million people, I wonder at the odds of such a double coincidence.

Then I realise it is no coincidence: I am travelling in a place of great connectedness. The sentient slum abounds.

- Mumbal Mosalc

Bombay, Mumbai, call it what you will. Extraordinary. A sea of people. Walking, sleeping, copulating, scratching, shitting, selling, begging, grovelling, eating, praying, working. Non-stop. Twenty-four hours a day. In an infinity of forms and pace. A multitude curtailed in bursting space. A tight balloon of concrete, bricks, mortar, tarmac, pavement, cardboard. Holding fast an ever-increasing mass of people. People snoring on the streets at any time of the day. Women, men, kids, lathering soap on their crowded bodies, pouring buckets of silvery water to rinse themselves between rushing cars. Old, young, everyone, going about their business and ablutions in full public view with innocence, without shame. A relentless seething tide of humanity, in the fullness of itself. Splendid and horrific. It is biblical. It is ancient. It is an absolutely dense, spilt- 
condensed milk experience. Much is confronting, challenging on many levels. Not for the fainthearted or weak of stomach. Sensitivity testing. Taboo treading. The most magnificent girls, staggeringly pretty, clad in radiant saris rising up from the pavement as you pass, wiping the sleep from their dark eyes and squatting to piss, right there, in the midst of the throng. Jeez, and those lepers with stumps, imploring with beautiful eyes: 'Please Uncle, small change. One rupee, please Uncle?' Dwarves and professional cripples on rolling boards, beaming when greeted and acknowledged. Posing proudly on muscular arms and broken little legs. Everywhere and unconcealed, the freakish scree of humanity. The exhaustion of space giving them no place to be hidden.

In the depths of a great concrete high-rise resettlement block, I meet a powerful figure of a man, poised on a chair. An Aryan warrior just crossed the Indus. Barrelchested. Massive neck and arms. Pleased to see a stranger, he invites me into his home. Leaping off the chair, he scuttles inside on his hands, for, desperately, he has no legs. Within, I meet his striking but sad-looking wife and two teenage daughters. We talk with the smiling teeth of different languages.

Or a cricket match in a landscape of filth and litter. Plastic. Rags. Rotting waste. Raw sewerage seeping. Flooding green pools of stagnant tannery water. Stinking. And 'Tendulka' is at the crease, batting for India. A bright-eyed scamp wearing an embroidered Muslim kepi. A crowd of small boys and girls (some in veils) race for the struck ball, running barefoot through the spray of septic filth. 'FOUR!'

And on the other side of the cash divide. On a warm evening, I sit in the gentle paper lantern-lit Horniman Park, watching a performance of southern Indian folkloric dance. Three drummers drumming. A blood-thumping, spine-chilling, goose-flesh staccato of hand-slamming beats in many overlapping rhythms. From the crepuscular wings, a woman out of a Mogul painting insinuates herself on stage. All massive eyes and treble-clef arms, bearing, wearing, a scarlet pharaoh headpiece like a demijohn on her head. It must weigh a lot. Marvellous mime of fingers, arms and eyes. Incomprehensible. Swaying. Shimmering. Gleaming in a raging oil-lamp light. Scarlet, vermilion, magenta, gold, brass and Kohl-black eyes. She does a weird eyebrow wiggle. Repeatedly. Almost like an epileptic tic. Quite disturbing. A lexicon of gestures, not understood. Yet fascinating. Something visceral and arcanely familiar.

Later, I join a young Indian woman of wealth (an Oxford graduate of the upper caste working in the SPARC offices) in a dark, smoky bar, where I meet her lively 
chums. An eye-burning, asthmatic interior. Dreadful, pricey gin and the rich uncloseted fraternity of India, travelled and dilettante. The girl sighs constantly. A young, rather spoilt hothouse intellectual, over-rich, neglected and, sadly, superfluous. Dallying in grungy spaces, hanging with the arty young men. Yearning for some Lawrencian romance, but paralysed by her taboos. The social mores of her caste restrain and inhibit her biology. While outside on the street the cycle of life goes on regardless. Both the street and mansion each have their poverty. One of circumstance, the other of life. The perennial contradiction of India.

Leopold Nicolai Podlashuc is completing a PhD at the University of Technology, Sydney.

\footnotetext{
-NOTES

${ }^{1}$ Arjun Appadurai, 'Deep Democracy: Urban Governmentality and the Horizon of Politics', Environment and Urbanization, vol. 13, no. 2, October 2001

<http://www.soc.iastate.edu/soc535a/Readings\%20PDF/Appadurai.pdf>.

${ }^{2}$ South African Homeless People's Federation.

${ }^{3}$ Society for Promotion of Area Resource Centres.

${ }^{4}$ A collective of women pavement and slum dwellers.
} 